\title{
LOCAL VEGETABLES TRADITIONALLY USED FOR REDUCING HYPERGLYCEMIA IN SURAT THANI PROVINCE, THAILAND
}

\author{
ARAYA PRANPRAWIT* \\ Department of Community Health, Faculty of Science and Technology, Suratthani Rajabhat University, Suratthani, Thailand. \\ Email: araya.sru@gmail.com
}

Received: 04 June 2018, Revised and Accepted: 29 November 2018

\section{ABSTRACT}

Objective: High blood sugar can lead to diabetes, a chronic illness which is becoming a public health challenge in the $21^{\text {st }}$ century in Thailand. The aim of this study was to survey the local vegetables traditionally used by traditional healers for reducing hyperglycemia and normally consumed in Surat Thani Province and to analyze the total phenolic content (TPC) in these local vegetables.

Methods: Data were collected using in-depth interview of traditional healers from nine districts of Surat Thani Province, and TPC of the extracts of vegetables collected was determined by Folin-Ciocalteu reagent method.

Results: A total of 16 local vegetables have been found to be used by traditional healers for reducing blood sugar: Ocimun tenuiflorum Linn., Musa acuminate Colla, Cassia siamea (Lam.) Irwin and Barneby, Coccinia grandis (L.) Voigt, Pandanus amaryllifolius Roxb., Vigna unguiculata (L.) Walp. subsp. Unguiculata, Ipomoea aquatic Forssk., Phyllanthus emblica Linn., Solanum torvum Sw., Anacardium occidentale Linn., Momordica charantia Linn., Moringa oleifera Lamk., Archidendron jiringa Nielsen, Azadirachta indica A. Juss. var. Indica, Parkia speciosa Hassk., and Micromelum minutum (G. Forst.) Wight and Arn. In addition, the TPC results showed that the extract of A. occidentale Linn. exhibited the highest TPC (8.0 $\pm 0.11 \mathrm{mg}$ gallic acid equivalent (GAE)/g fresh weight) followed by the extract of M. minutum (G. Forst.) Wight and Arn. (3.99 $\pm 0.10 \mathrm{mg}$ GAE/g fresh weight).

Conclusion: Local vegetables in Surat Thani were shown to be a good source of TPC, and the data from this study can serve as fundamental information for promoting consumption of selected local vegetables for diabetes prevention in the future.

Keywords: Local vegetables, Blood sugar, Total phenolic content, Surat Thani Province.

(C) 2019The Authors. Published by Innovare Academic Sciences Pvt Ltd. This is an open accessarticle under the CC BY license (http://creativecommons. org/licenses/by/4. 0/) DOI: http://dx.doi.org/10.22159/ijap.2019.v11s3.M0008

\section{INTRODUCTION}

Hyperglycemia is one of the characteristic features of the metabolic syndrome (also known as syndrome $\mathrm{X}$ ), which is associated with an increased risk of developing type II diabetes [1]. According to the statistics of the International Diabetes Federation (2017), it is estimated that around 1 in 11 of the adult population globally have diabetes. This number of people with diabetes is increasing rapidly in every country due to an imbalance in dietary intake, physical inactivity, and excess body weight as well as to genetic and physiological factors [2]. Similarly to Thailand, data from the Ministry of Public Health in 2017 reported the prevalence of diabetes rose from $2.3 \%$ in 1991 to $8.9 \%$ or approximately 5 million individuals in 2014.

A number of studies have provided evidence that consumption of fruits and vegetables may reduce the risk of various diseases such as cancer [3] and cardiovascular disease [4], including type II diabetes mellitus, for example, El-Beshbishy and Bahashwan (2012) demonstrated that aqueous extracted from basil (Ocimum basilicum) inhibit alpha-amylase and alpha-glucosidase activities, the enzymes involved in breaking down starch, in vitro [5]. In addition, the review of Reyad-ul-ferdous et al., in 2015, suggested that extract of Abutilon indicum, plant grown extensively in Bangladesh, India, and Pakistan, can inhibit glucose absorption and stimulates insulin secretion in streptozotocin-induced diabetic rodents [6]. The authors also revealed that phenolic compounds in plants account for the observed beneficial effects of the extracts.

Medicinal plants have attracted public interest recently and have been proposed as an alternative approach to prevent and treat diabetes mellitus due to less side effects of natural products and toxicity of modern synthetic drugs used for reducing blood sugar in diabetic patients such as acarbose, miglitol, or voglibose [7]. However, the evidence of beneficial effects of local vegetables, which are commonly consumed, especially in the area of Southern Thailand, is scarce and need more investigation. Therefore, the objectives of this study were (1) to survey the local vegetables used by traditional healers in Surat Thani Province for reducing hyperglycemia and (2) to determine the total phenolic content (TPC) in the extracts of these local vegetables.

\section{METHODS}

\section{The study area}

The area of the survey is located between $8^{\circ} 38^{\prime}$ and $9^{\circ} 34^{\prime} 1$ atitudes and $98^{\circ} 58^{\prime}$ and $99^{\circ} 56^{\prime}$ longitudes in the Southern part of Thailand, Surat Thani Province. Nine districts across this region were randomly selected for data collection, including: Muang (no. 1), Kanchanadit (no. 2), Koh Samui (no. 4), Chaiya (no. 6), Khiri rat Nikhom (no. 8), Tha Chang (no. 11), Khian-Sa (no. 14), Wiang Sa (no. 15), and Phunphin (no. 17), as highlighted in Fig. 1.

\section{Data collection}

The study was conducted during March 2015-February 2016. Data related to the utilization of local vegetables for reducing hyperglycemia were first reviewed from the literature search of traditional remedies for the treatment of diabetes in Southern Thailand and then rechecked using in-depth interview of traditional healers from nine districts in Surat Thani Province. Local healers in each of the nine districts were selected purposively, based on data of registered folk medicinal practitioners of the Department of Thai Traditional Medicine, Surat Thani Provincial Health Office. Semi-structure questionnaire was used for collecting the ethnomedicinal data: Locality, vernacular plant names, plant parts used, method of preparation, and method of administration. 


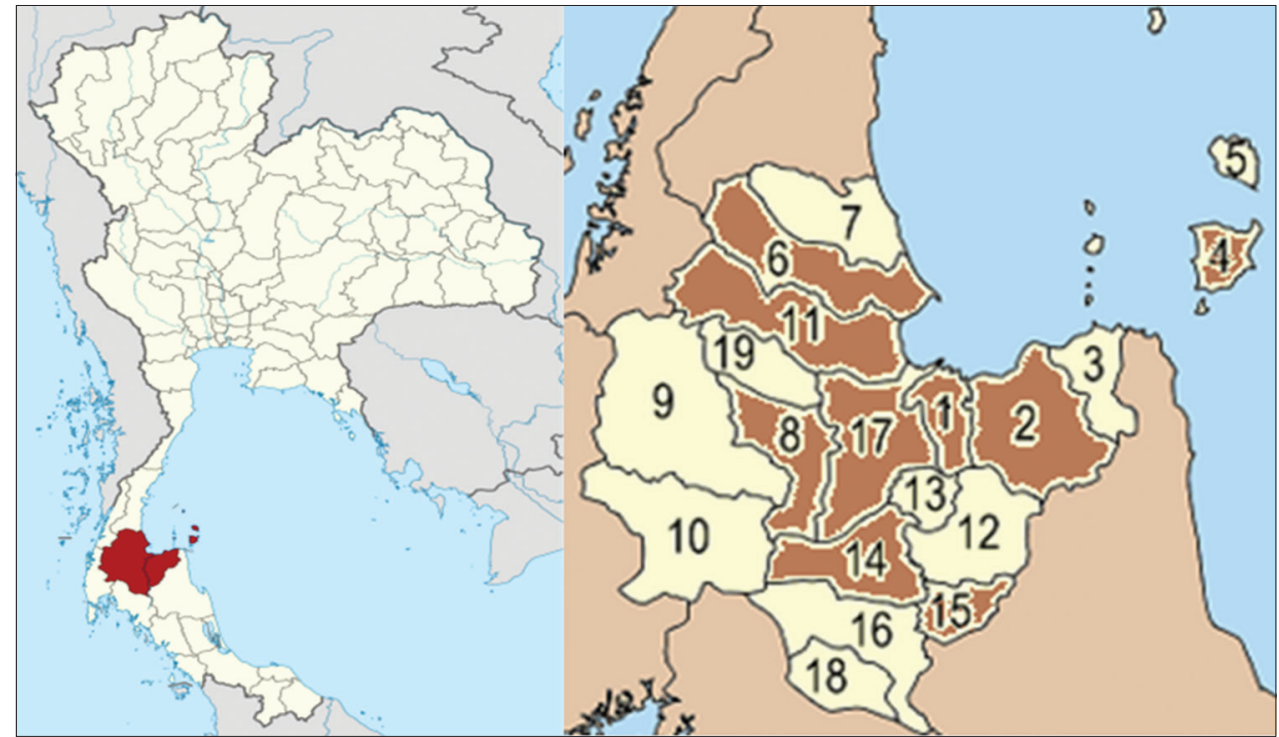

Fig. 1: Study area - Surat Thani Province, Thailand (modified from https://no.wikipedia.org/wiki/Surat_Thani_(Province))

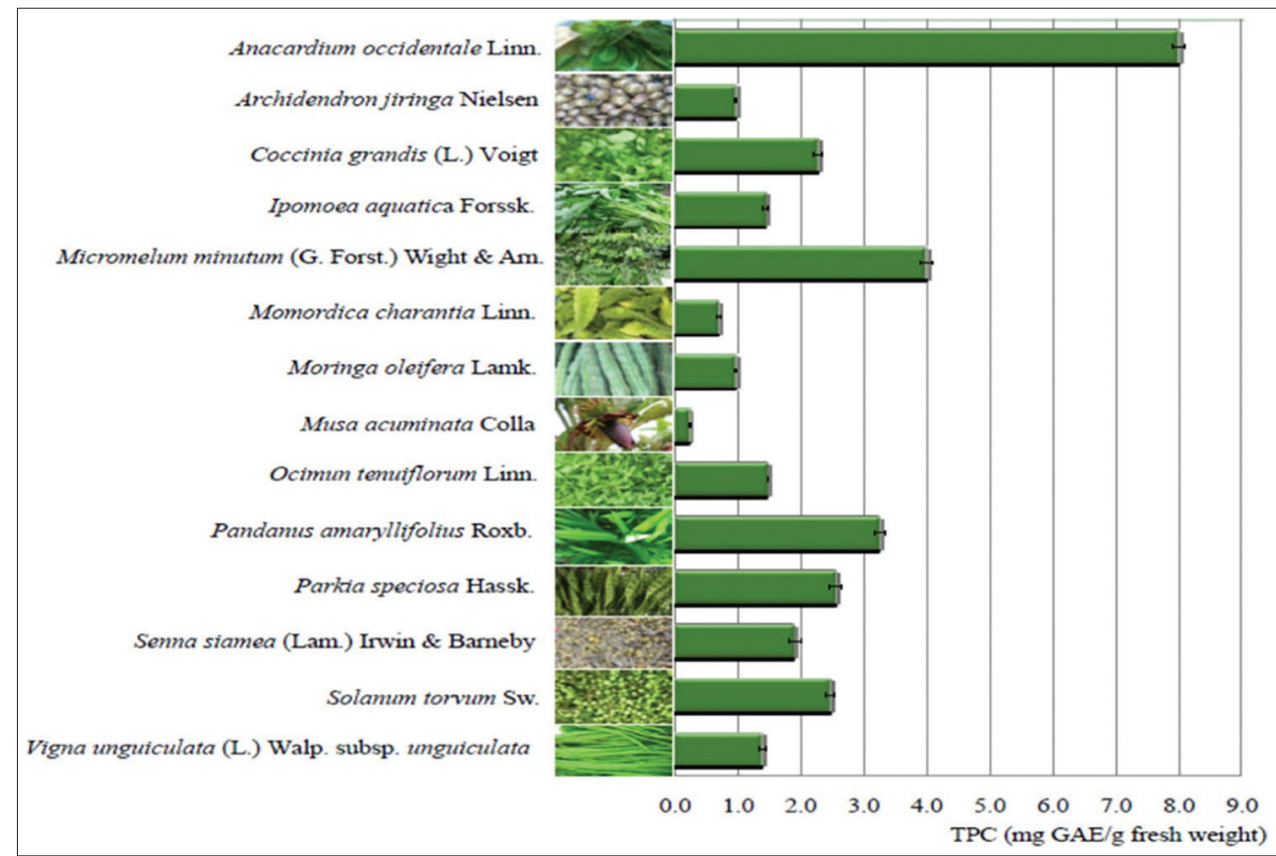

Fig. 2: Total phenolic content in a water extract of local vegetables used by traditional healers for reducing hyperglycemia. Results are expressed as mean $\pm \mathrm{SD}$ of triplicate samples

In addition, the samples of local vegetables, as pointed out by the informants (traditional healers), were also collected from the study site for checking the scientific name and determining TPC.

\section{Preparation of aqueous plant extracts}

Vegetables were collected from three local markets in Muang district of Surat Thani, during the month of August 2015. All plants were extracted using water since this solvent may better represent the normal consumption than using organic solvents. The preparation was done by grinding $50 \mathrm{~g}$ of the fresh plant with $50 \mathrm{ml}$ of ultrapure Milli- $\mathrm{Q}$ water using a small food processor (Moulinex Optiblend Duo, KRUPS, France). The mixture was then centrifuged at 4000 rpm for 10 min (Universal 32, Hettich, D-78532, Tuttlingen, Germany) and the supernatant was collected for analysis.

\section{Determination of TPC}

TPC was measured in three independent experiments using a FolinCiocalteu procedure as used by Waterhouse (2002) with some modification [8]. Briefly, $1 \mathrm{ml}$ of plant extract was added to $1 \mathrm{ml}$ of $50 \%$ Folin-Ciocalteu phenol reagent (diluted 1:1 in distilled water) and allowed to react for $5 \mathrm{~min}$ at room temperature. Subsequently, $1 \mathrm{ml}$ of $2 \%$ sodium carbonate solution $\left(\mathrm{Na}_{2} \mathrm{CO}_{3}\right)$ was added, adjusted volume with distilled water to $10 \mathrm{ml}$ and incubated for $30 \mathrm{~min}$ at room temperature. The absorbance of the extracts and a matching blank was spectrophotometrically measured at $765 \mathrm{~nm}$ using a spectrophotometer (UV1100 Techcomp, China). A standard curve was prepared using different concentrations $(0-1000 \mu \mathrm{g} / \mathrm{mL})$ of aqueous gallic acid solution. TPC was calculated as gallic acid equivalent (GAE) mg per $\mathrm{g}$ of the sample based on a standard curve.

\section{RESULTS AND DISCUSSION}

Ethnobotanical data

The results of the present study showed that 16 local vegetables which are commonly consumed in Surat Thani Province and traditionally 
Table 1: Local vegetables used for reducing hyperglycemia/treatment of diabetes by traditional healers in Surat Thani Province

\begin{tabular}{|c|c|c|c|c|c|}
\hline Scientific name & Family & Local name & Area found* & Part used & Uses/Preparation \\
\hline $\begin{array}{l}\text { Anacardium occidentale } \\
\text { Linn. }\end{array}$ & Anacardiaceae & $\begin{array}{l}\text { Mamuang } \\
\text {-himmaphan }\end{array}$ & $\begin{array}{l}1,2,4,6,8,11 \\
14,15,17\end{array}$ & Aerial parts & Consumed fresh with diet \\
\hline $\begin{array}{l}\text { Archidendron jiringa } \\
\text { Nielsen }\end{array}$ & $\begin{array}{l}\text { Leguminosae } \\
\text { - Mimosoideae }\end{array}$ & Look-niang & $1,8,14,15,17$ & Seed and seed coat & $\begin{array}{l}\text { Cut into small pieces and consumed } \\
\text { fresh, or used for cooking }\end{array}$ \\
\hline $\begin{array}{l}\text { Azadirachta indica } \\
\text { A. Juss. var. Indica }\end{array}$ & Meliaceae & Sadao & 11,14 & Aerial parts/leaves & $\begin{array}{l}\text { Dried and boiled with hot water. The } \\
\text { infusion is drunk daily, or } \\
\text { Balanced and consumed with a diet }\end{array}$ \\
\hline $\begin{array}{l}\text { Ipomoea aquatic } \\
\text { Forssk. }\end{array}$ & Convolvula-ceae & Phak-bung & $\begin{array}{l}1,2,4,6,8,11 \\
14,15,17\end{array}$ & Whole plants & $\begin{array}{l}\text { Blanched and consumed with diet, or } \\
\text { used for cooking }\end{array}$ \\
\hline $\begin{array}{l}\text { Micromelum } \\
\text { minutum (G. Forst.) }\end{array}$ & Rutaceae & Samui, Hatsakhun & $\begin{array}{l}1,2,4,11,14 \\
15,17\end{array}$ & Aerial parts/leaves & Consumed fresh with diet \\
\hline $\begin{array}{l}\text { Wight and Arn. } \\
\text { Momordica charantia } \\
\text { Linn. }\end{array}$ & Cucurbitaceae & Mara-Kee-nok & $1,2,4,6,11,17$ & Fruits & $\begin{array}{l}\text { Blanched or consumed fresh with diet } \\
\text { Processed into a refreshing beverage, or } \\
\text { Dried and soaked in hot water for } \\
\text { drinking }\end{array}$ \\
\hline Moringa oleifera Lamk. & Moringaceae & Ma-rum & $1,11,14,17$ & Leave, pods & $\begin{array}{l}\text { Leaves are dried and boiled with water } \\
\text { for drinking. Seeds used for cooking }\end{array}$ \\
\hline Musa acuminate Colla & Musaceae & Hua-plee & $\begin{array}{l}1,2,4,6,8 \\
11,14,15 \\
17\end{array}$ & Flowers & Blanched or consumed fresh with diet \\
\hline $\begin{array}{l}\text { Ocimun tenuiflorum } \\
\text { Linn. }\end{array}$ & Lamiaceae & Ka-phrao & $\begin{array}{l}1,2,4,6,8 \\
11,14,15 \\
17\end{array}$ & Leaves & $\begin{array}{l}\text { Leaves are dried and soaked in hot } \\
\text { water. The infusion is drunk daily }\end{array}$ \\
\hline $\begin{array}{l}\text { Pandanus amaryllifolius } \\
\text { Roxb. }\end{array}$ & Pandanaceae & Toei-hom & $\begin{array}{l}1,2,4,6,11 \\
14,17\end{array}$ & Roots & $\begin{array}{l}\text { Roots are cut into small pieces and } \\
\text { boiled with hot water, filtered, and } \\
\text { drunk regularly }\end{array}$ \\
\hline Parkia speciosa Hassk. & $\begin{array}{l}\text { Leguminosae } \\
\text { - Mimosoideae }\end{array}$ & Sa-tor & $\begin{array}{l}1,2,4,6,8 \\
11,14,15 \\
17\end{array}$ & $\begin{array}{l}\text { Leaves, pods, } \\
\text { seeds }\end{array}$ & $\begin{array}{l}\text { Leaves and pods are dried and boiled } \\
\text { with water for drinking. Seeds used for } \\
\text { cooking }\end{array}$ \\
\hline $\begin{array}{l}\text { Senna siamea (Lam.) } \\
\text { Irwin and Berneby }\end{array}$ & $\begin{array}{l}\text { Leguminosae } \\
\text { - Caesalpinioideae }\end{array}$ & Khi-lek & $\begin{array}{l}1,2,6,8,11 \\
14,15,17\end{array}$ & $\begin{array}{l}\text { Aerial parts/ } \\
\text { flowers }\end{array}$ & Used for cooking purposes \\
\hline Solanum torvum Sw. & Solanaceae & Ma-khuea-phuang & $\begin{array}{l}1,2,4,6,8 \\
11,14,17\end{array}$ & Fruits & Consumed fresh or use for cooking \\
\hline $\begin{array}{l}\text { Vigna unguiculata (L.) } \\
\text { Walp. subsp. } \\
\text { unguiculata }\end{array}$ & $\begin{array}{l}\text { Leguminosae } \\
\text { - Papilionoideae }\end{array}$ & Thua-fak-yao & $\begin{array}{l}1,2,4,6,8 \\
11,14,15,17\end{array}$ & Pods & $\begin{array}{l}\text { Consumed fresh, blanched or used for } \\
\text { cooking }\end{array}$ \\
\hline
\end{tabular}

*1=Muang, 2=Kanchanadit, 4=Koh-Samui, 6=Chaiya, 8=Khiri rat Nikhom, 11=Tha-Chang, 14=Khian-Sa, 15=Wiang-Sa and 17=Phunphin

used by traditional healers for reducing blood sugar in the study area (Tables 1), namely: Ocimun tenuiflorum Linn. (holy basil), Musa acuminate Colla (banana blossom), Cassia siamea (Lam.) Irwin and Barneby (Thai copperpod), Coccinia grandis (L.) Voigt (ivy gourd), Pandanus amaryllifolius Roxb. (pandanus palm), Vigna unguiculata (L.) Walp. subsp. Unguiculata (yard long bean), Ipomoea aquatic Forssk. (morning glory), Phyllanthus emblica Linn. (Indian gooseberry), Solanum torvum Sw. (Turkey berry), Anacardium occidentale Linn. (cashew leaves), Momordica charantia Linn. (bitter gourd), Moringa oleifera Lamk. (horse radish tree), Archidendron jiringa Nielsen (Djenkol bean), Azadirachta indica A. Juss. var. indica (neem leaves), Parkia speciosa Hassk. (Stink bean), and Micromelum minutum (G. Forst.) Wight and Arn. (Hatsa khun).

The number of plant species found in this study is lower than other medicinal plants survey studies $[9,10]$ as we recorded only the edible plants that are normally consumed as vegetables in the diet in Surat Thani region. All of the plants recorded were growing either in the peripheral of the homesteads or were available for consumption in the local market on a regular basis. Most of them can be grown all year round, only for A. indica A. Juss. var. indica and P. emblica Linn. are available especially in the winter season, and A. jiringa Nielsen and P. speciosa Hassk., which can be grown only in the rainy season.

Among these vegetables, the families most frequently used were Leguminosae ( 4 species), and the parts of plants most used for the treatment of diabetes/reducing blood sugar were leaves, fruits, and seeds, respectively. Sometimes, plants were used in combinations for enhanced antidiabetic efficacy. In addition, the preparation method was mostly infusion with hot water and taken orally or consumed fresh/ cooking.

TPC

The TPC was determined by Folin-Ciocalteu Reagents, and the results (Fig. 2) showed that the extract of $A$. occidentale Linn. exhibited the highest TPC $(8.0 \pm 0.11 \mathrm{mg} \mathrm{GAE} / \mathrm{g}$ fresh weight), followed by the extract of M. minutum (G. Forst.) Wight and Arn. (3.99 $\pm 0.10 \mathrm{mg} \mathrm{GAE} / \mathrm{g}$ fresh weight), and M. acuminate Colla extract showed the lowest TPC value $(0.24 \pm 0.02 \mathrm{mg} \mathrm{GAE} / \mathrm{g}$ fresh weight).

The TPC results of this study are in line with the study of Chanudom and Tangpong (2011), which reported that among 13 Thai traditional 
plants investigated, A. occidentale Linn. extracted with ethanol were found to have high content of total phenolic and possess the highest total antioxidant capacity compared to other plants [11]. Since the TPC in the present study was extracted using water, the concentration was considerably lower than as reported in other studies for Thai local vegetables $[11,12]$. However, this solvent may better represent the normal consumption than using organic solvents.

Previous studies found the dose-dependent relationship between TPC and the activities of alpha-amylase and alpha-glucosidase, the enzymes involved in breaking down starch, in vitro $[13,14]$. In addition, the animal study of Zhang et al. [15] further demonstrated that the phenolic content found also correlates with the reduction of blood glucose levels in diabetic mice. For this reason, Thai local vegetables with high phenolic content can be good natural sources for chronic non-communicable disease prevention and control, especially diabetes mellitus.

Some study limitations should be noted. Even though the TPC analysis was performed in three independent experiments, which was prepared from vegetables collected from three different markets, they were all from a single district, Muang Surat Thani. In addition, only 14 out of 16 local vegetables can be collected for TPC analysis by the time of sample collection (August, 2015), except A. indica A. Juss. var. indica (Sadao), and P. emblica Linn. (Ma-kham-pom) because these two local vegetables are available only in the winter season, between November and January.

\section{CONCLUSION}

The survey documented 16 local vegetables which are commonly consumed in households and traditionally used by traditional healers for reducing blood sugar in Surat Thani Province. Among these plants, A. occidentale Linn. (cashew leaves) exhibited the highest TPC, which may provide health-promoting advantages. The data from this study can serve as fundamental information for promoting consumption of selected local vegetables for diabetes prevention and treatment in the future.

\section{ACKNOWLEDGMENT}

This research was supported by a grant from Surat Thani Rajabhat University, and the author wish to thanks all traditional healers for their hospitality and for taking their time to share their traditional knowledge with the research team.

\section{REFERENCES}

1. Streja D. Metabolic syndrome and other factors associated with increased risk of diabetes. Clin Cornerstone 2004;6 Suppl 3:S14-29.

2. International Diabetes Federation. IDF Diabetes Atlas. $8^{\text {th }}$ ed. Brussels: International Diabetes Federation; 2017. http://www.diabetesatlas.org/ resources/2017-atlas.html.

3. Yi W, Fischer J, Krewer G, Akoh CC. Phenolic compounds from blueberries can inhibit colon cancer cell proliferation and induce apoptosis. J Agric Food Chem 2005;53:7320-9.

4. Basu A, Du M, Leyva MJ, Sanchez K, Betts NM, Wu M, et al. Blueberries decrease cardiovascular risk factors in obese men and women with metabolic syndrome. J Nutr 2010;140:1582-7.

5. El-Beshbishy HA, Bahashwan SA. Hypoglycemic effect of basil (Ocimum basilicum) aqueous extract is mediated through inhibition of $\alpha$-glucosidase and $\alpha$-amylase activities: An in vitro study. Toxico Ind Health 2012;28:42-50.

6. Reyad-ul-ferdous MD, Rahman M, Mahamud K, Ayshi SS, Sohel MD. Pharmacologicals and phytochemicals potential of Abutilon indicum: A comprehensive review. Am J Bio Sci 2015;3:5-11.

7. Dong HQ, Li M, Zhu F, Liu FL, Huang JB. Inhibitory potential of trilobatin from Lithocarpus polystachyus Rehd against $\alpha$-glucosidase and $\alpha$-amylase linked to Type 2 diabetes. Food Chem 2012;130:261-6.

8. Waterhouse AL. Determination of total phenolics. In: Wrolstad RE, editor. Current Protocols in Food Analytical Chemistry. New York: Wiley and Sons; 2002.p. 11.1.1-8.

9. Jouad H, Haloui M, Rhiouani H, El Hilaly J, Eddouks M. Ethnobotanical survey of medicinal plants used for the treatment of diabetes, cardiac and renal diseases in the North centre region of Morocco (FezBoulemane). J Ethnopharm 2001;77:175-82.

10. Eddouks M, Maghrani M, Lemhadri A, Ouahidi ML, Jouad H. Ethnopharmacological survey of medicinal plants used for the treatment of diabetes mellitus, hypertension and cardiac diseases in the South-east region of Morocco (Tafilalet). J Ethnopharmacol 2002;82:97-103.

11. Chanudom L, Tangpong J. Total phenolic content, antioxidant and antimicrobial activities from 13 Thai traditional plants. Wichcha J Nakhon Si Thammarat Rajabhat Univ 2011;30:1-11.

12. Saenthaweesuk S, Jongtamklang D, Somchan T, Thobunluepop P. Total phenolics content, antioxidant and antimicrobial activities of some herbs. Khon Kaen Agric J 2012;40:480-3.

13. Apostolidis E, Lee CM. In vitro potential of Ascophyllum nodosum phenolic antioxidant-mediated $\alpha$-glucosidase and $\alpha$-amylase inhibition. J Food Sci 2010;75:H97-102

14. Mousinho NM, van Tonder JJ, Steenkamp V. In vitro anti-diabetic activity of Sclerocarya birrea and Ziziphus mucronata. Nat Prod Commun 2013;8:1279-84

15. Zhang J, Tiller C, Shen J, Wang C, Girouard GS, Dennis D, et al. Antidiabetic properties of polysaccharide- and polyphenolic-enriched fractions from the brown seaweed Ascophyllum nodosum. Can J Physiol Pharmacol 2007;85:1116-23 